\title{
Mini-Review
}

\section{Bioprospecting plant-associated microbiomes}

\author{
Christina A. Müller ${ }^{a, b}$, Melanie M. Obermeier ${ }^{b}$ and Gabriele Berga \\ alnstitute of Environmental Biotechnology, Graz University of Technology, 8010 Graz, Petersgasse 12, \\ Austria

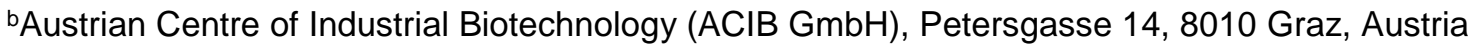 \\ Correspondence: \\ Christina A. Müller, \\ Institute of Environmental Biotechnology, \\ Graz University of Technology, Petersgasse 12, \\ 8010 Graz, Austria \\ e-mail: christina.mueller@tugraz.at
}

Submitted to: Journal of Biotechnology

Special Issue dedicated to Helmut Schwab 


\begin{abstract}
There is growing demand for new bioactive compounds and biologicals for the pharmaceutical, agro- and food industries. Plant-associated microbes present an attractive and promising source to this end, but are nearly unexploited. Therefore, bioprospecting of plant microbiomes is gaining more and more attention. Due to their highly specialized and co-evolved genetic pool, plant microbiomes host a rich secondary metabolism. This article highlights the potential detection and use of secondary metabolites and enzymes derived from plant-associated microorganisms in biotechnology. As an example we summarize the findings from the moss microbiome with special focus on the genus Sphagnum and its biotechnological potential for the discovery of novel microorganisms and bioactive molecules. The selected examples illustrate unique and yet untapped properties of plant-associated microbiomes, which are an immense treasure box for future research.
\end{abstract}




\section{Introduction}

Bioprospecting is the process of discovery and commercialization of new products based on biological resources (Strobel and Daisy, 2003). A growing need for new bioactive compounds in the pharmaceutical (e.g. antibiotics against multi-resistant pathogens) and the agro- and food industries (e.g. agrochemicals, biocontrol products, food additives) stresses the importance of prospecting for novel bio-resources (Berg et al., 2013; Woolhouse and Farrar, 2014). Since the chemical diversity of compounds as comprised in biological resources is higher than synthetic chemistry achieves, bio-resources have great potential to hold a manifold of promising compounds for biotechnological application (Bérdy, 2012; Nováková and Farkašovský, 2013). Plants have been described as one of the richest sources of valuable bioactive natural products (McChesney et al., 2007). Progress in the -omics era, including next-generation sequencing (metagenomics, metatranscriptomics) and microscopic advances, has changed our view on eukaryotic hosts and the role of microbial diversity and microbial functions (Jansson et al., 2012; Cardinale, 2014; Mendes and Raaijmakers, 2015). Nowadays, we consider plants, like humans and other eukaryotic hosts, as meta-organisms that undergoes a tight symbiotic relationship with their microbiome (Bulgarelli et al., 2012; Hirsch and Mauchline, 2012; Lundberg et al., 2012).

Each plant is colonized by more than 1,000 microbial species, which are to a high degree not cultivable. In addition, plants are divided into specific niches for microorganisms, where biotic and abiotic factors shape specific microbial communities. While the rhizosphere has been well-studied for more than 100 years (Philippot et al., 2013), the phyllosphere and especially the endosphere are currently under intense investigation (Vorholt, 2012; Hardoim et al., 2015). Moreover, each plant microbiome has due to the plant-specific secondary metabolism and physiology a specific composition (Berg and Smalla, 2009). This depends on the plant family, for instance dicotyledonous plants have developed a richer secondary metabolism than monocotyledonous plants. Recently it was shown that breeding has a strong impact on the plant microbiome as well, and cultivar-specific effects were identified (Schlaeppi et al., 2014; Cardinale et al., 2015; PérezJaramillo et al., 2015). Thereby, the microbiome fulfils multiple functions for the host health, like pathogen defense and contribution to stress tolerance under adverse environmental conditions and further supports growth and nutrient supply (Berg, 2009; Berg et al., 2013; Bragina et al., 2014; Grube et al., 2015).

While the potential of the microbiome to influence the host is now well-recognized (Blaser, 2014; Berg et al., 2015), the diversity of metabolites that are synthetized by the microbiota is largely unexplored (Berg et al., 2014; Nunes-Alves, 2014). During the last decades it was shown that single cultivable microorganisms represent a plenteous source for novel enzymes and bioactive 
compounds: around 70, 000 natural products derived from microorganisms were reported with almost half of them showing bioactive traits (Bérdy, 2012). Altogether, these facts underline the high diversity of indigenous microbial populations in plant microbiomes, and supports their exploitation for biotechnological purposes, for biocatalytic processes and plant protection, or in the pharmaceutical industry (Harvey, 2008; Duke et al., 2010).

Metagenomics is one means that facilitates examination of the entire genetic pool comprised by (plant) microbiomes, thereby providing access to the potential of the high share of uncultivable microbes. The field of metagenomics has been intensively reviewed in recent time, which illustrates the great interest within the scientific community spanning a wide range of research areas from ecology over medicine to biotechnology (Wang et al., 2014; Banerjee et al., 2015; Coughlan et al., 2015; Cowan et al., 2015; Faust et al., 2015; Garza and Dutilh, 2015; Ravin et al., 2015; Roossinck et al., 2015). Briefly, metagenomics is the study of the combined genomes of all the organisms present at site without culturing them first (Handelsman, 2004). Upon extraction of the total environmental DNA it can either be examined at the sequence level or function driven. Sequence based analysis obviously requires the DNA to be sequenced, which commonly involves random shot gun sequencing (Abbasian et al., 2015). In contrast, when expressed heterologous, the metagenome can be screened for certain, desired activities by subjecting the metagenomic library to specifically designed screening assays (Gabor et al., 2007). Bioprospecting towards novel enzymes and bioactive compounds has been frequently performed using environmental samples originated from soil, marine environments and microbiota associated to mammals (e.g. the human gut microbiome), but rarely employing plant-associated microorganisms.

Here we present examples that highlight the enormous microbial and functional diversity, as well as the biosynthetic potential of plant-associated microbiomes for bioprospecting approaches.

\section{Functional and structural insights in plant microbiomes from metagenomics}

While the structural diversity of plant microbiomes is well-studied now by amplicon sequencing, it is difficult to find general genetic markers to analyze functional diversity. For this purpose, metagenomic datasets have to be compared and studied in depth. Interestingly, microbiome functions are more similar across different environments than previously thought. For example, Ramírez-Puebla et al. (2013) discussed extensively on similar functional traits in the gut and root microbiome. Based on deeper insights obtained by omics technologies, Mendes and Raaijmakers (2015) recently presented their concept that the structure and function of rhizosphere and gut 
microbiomes show cross-kingdom similarities. This concept was extended by Berg et al. (2015) to ecological rules. To date only a few studies have deciphered the functional diversity of plant microbiota employing shotgun next generation sequencing approaches (rev. in Knief, 2014). For instance, in depth analysis of the Sphagnum moss metagenome revealed high functional diversity within the microbiome and a higher structural diversity as previously detected with other methods (amplicon sequencing or cultivation-dependent methods) (Bragina et al., 2014).

In this section we focus on functional and structural diversity of plant metagenomes as summarized in Table 1, which are important criteria when prospecting for novel bioactive compounds. Based on phylogenetic analysis of plant metagenomic data it was demonstrated that bacterial diversity in higher plants (rhizosphere, phyllosphere, endosphere) is remarkably high, even though it is in general lower than the microbial diversity in the surrounding bulk soil (Delmotte et al., 2009; Bulgarelli et al., 2015). High abundance of bacterial taxa in the rhizosphere or phyllosphere of rice, barley, moss, lettuce and soybean belong predominantly to the phyla Proteobacteria, Actinobacteria, Bacteroidetes, Firmicutes, and Acidobacteria. Less abundant but highly diverse phyla with functionally outstanding properties are also present, for example Cyanobacteria, Deinococcus, and Chloroflexi (Delmotte et al., 2009; van der Lelie et al., 2012; Kröber et al., 2014; Bragina et al., 2014; Bulgarelli et al., 2015). The functional diversity of the aforementioned plant-microbiomes has been explored in relation to the plant compartment. In barley roots and rhizosphere, the authors found significant enrichment of biological functions coding for adhesion, stress response, secretion, host-pathogen, microbe-microbe and phagemicrobe interactions, as well as iron mobilization and sugar transport (Bulgarelli et al., 2015). In contrast, phyllosphere bacterial communities in clover, soybean and Arabidopsis thaliana plants were characterized by high expression of outer membrane proteins (porins, TonB receptors) and ABC-transport systems for carbohydrates (maltose, glucose, sucrose) and amino acids, underlining the role of the phyllosphere microbiota for carbon utilization on the plant leaves (Delmotte et al., 2009).

Other groups have focused on the investigation of highly specialized microbial communities and their metabolic functions, for example on the distribution and abundance of phototrophic bacteria on the plant phyllosphere, with putative functions for light sensing and utilization (Atamna-Ismaeel et al., 2012a, 2012b). Here the authors employed metagenome data mining to elucidate the relative abundance of rhodopsin-based phototrophs and anoxygenic phototrophs on leaves of different plants (tamarisk, clover, rice, soybean, and Arabidopsis thaliana). Rhodopsin coding sequences (Atamna-Ismaeel et al., 2012b), as well as phototrophy-related genes (pufM, bchY, pufL) (Atamna-Ismaeel et al., 2012a), were used as genetic markers for in silico analysis. Several 
novel rhodopsin sequences were identified, especially in the tamarisk phyllosphere. These findings suggest the presence of highly diverse and phyllosphere-specific phototrophic species in the studied plant microbiomes. Similarly, van der Lelie et al. (2012) investigated the occurrence and enrichment of specialized indigenous microbial communities from poplar hard wood that are capable of decomposing or modifying lignin under anaerobic conditions. The biomass degrading community was dominated by species belonging to Clostridia, Bacteroidetes and Methanomicrobiales, but also by a novel biomass degrader bacterium displaying similarity to the genus Magnetospirillum, which may be involved in detoxification of aromatic metabolites. The poplar wood metagenome showed high abundance of carbohydrate active enzymes and also the presence of putative cellobiose dehydrogenases and new bacterial genes showing homology to fungal lignin oxidases.

\section{Bioactiva from plant-microbiomes: microbes, enzymes and secondary metabolites}

Microbes: The use of isolated microorganisms or microbial consortia as biological control agents (BCAs) is an outstanding alternative to conventional agricultural techniques (Berg et al., 2013). While in the past mainly microbes of soil or crop origin were selected, now native and endemic plants or mosses are in the focus of bioprospecting (Opelt et al., 2007; Zachow et al., 2007). Colonisation and plant-growth promotion were observed for several endophytic bacterial isolates from Sphagnum moss, belonging mainly to the genus Burkholderia, Pseudomonas, Flavobacterium, Serratia and Collimonas (Shcherbakov et al., 2013). Bacteria displaying stress protection and growth-promotion of economically relevant crops (e.g. maize and sugar beet) were isolated from alpine mosses, prime rose, and lichens (Zachow et al., 2013). A possible application of endophytic bacteria for bioremediation has also been discussed (Stępniewska and Kuźniar, 2013). It was further shown that microbes assist plants in pathogen defence. When Arabidopsis thaliana gets infected with Pseudomonas syringae pv. tomato it increasingly secretes malic acid which attracts Bacillus subtilis BF-17. The colonisation of root tissue triggers an immune response that aids the plant in antagonising the pathogen (Rudrappa et al., 2008). Raymond (2015) reported the production of ice-binding proteins by epiphytic bacteria in the moss Bryum argenteum grown in the Antarctica. This class of proteins are found mainly in cold-adapted microorganisms, protecting the plant against freezing damage, a property that could be exploited for crop protection strategies as well. These are only a few examples for bioactive microbes from plant microbiomes and a much longer list of studies exists (Berg, 2009; Berg et al., 2013).

Enzymes: Enzymes with novel activities are classical targets in microbial screenings that aim for an industrial application (Schmeisser et al., 2007). However, most enzyme discovery screenings to date have focused on analyzing metagenomic libraries from soil and marine environments or 
the human gut (Simon and Daniel, 2011). In the case of plant-associated microbiomes, detection of new enzymes have mainly been centered in the investigation of microbial activities that are directly related to antagonism or plant-growth promotion. Cell-wall degrading or lytic enzymes, like cellulases, glucanases, proteases, xylanases and chitinases have been detected in plantassociated microorganisms, especially in endophytic fungi and bacteria (Lumyong et al., 2002; Gayathri et al., 2010; Suryanarayanan et al., 2012; Robl et al., 2013) or rhizobacteria (Inbar and Chet, 1991; Frankowski et al., 2001; Ghyselinck et al., 2013; Castaneda-Alvarez et al., 2015). In this studies microbiota adapted to extreme conditions received much attention. Reactions as carried out during industrial processes require enzymes to possess not only high functionality and specificity, but also high stability at particular conditions. Hence, tolerance to high salt content, cold or elevated temperature and low or increased pH are desired traits (Elleuche et al., 2015) . Recent reports describe the discovery (functional screenings) and characterization of a novel salttolerant chitibiosidase for potential degradation of seafood waste, a new alkaline and thermostable esterase Est3K and lipase Lip3K, as well as the esterase EstGX2 that exhibits high stability at elevated temperatures and in the presence of organic solvents (Cretoiu et al., 2015; Gu et al., 2015; Kim et al., 2015). As in these studies, functional metagenomic screens are often performed on microbiota derived from various kinds of soil and ground (Coughlan et al., 2015), rather than on plant microbiomes. Plant associated microbes, however, are likely to hold new enzymes for industrial applications. As for polysaccharides, like starch and cellulose, that are widely used in food, textile, paper industry and bioethanol production among others, plant microbiomes most likely harbor microbes that express degrading enzymes with interesting features. Through activity based screening of a metagenomic library constructed from sugarcane bagasse the thermophilic endoglucanase GH9 and xylanase GH11 were isolated. Both enzymes, derived from the indigenous microbial fraction, were characterized as thermophilic with highest activity under slightly acidic conditions, which are interesting features for industrial application in cellulose degradation (Kanokratana et al., 2015). Likewise, several novel glycoside hydrolase genes (GHases) were identified in naturally occurring microbial biomass decay communities from poplar wood chips, after enrichment in an anaerobic bioreactor. By combination of metagenomic gene mining and fosmid library screening the authors succeeded in the isolation and cloning of 4 metagenomic GHases (Li et al., 2011). Despite the increasing number of novel enzymes detected in metagenomes in the last decades, only a very small fraction has been expressed and fully characterized to evaluate further utilization in industrial processes (Schmeisser et al., 2007). Meanwhile, the demand for functionally characterized biocatalysts is still growing. 
Secondary metabolites: Plants were suggested to select competent endophytes from the environment for their own ecological benefit (Hardoim et al., 2015). In accordance, a plethora of diverse and highly specialized secondary metabolites and enzymes are produced by the inhabiting microorganisms. Most bioprospecting campaigns have therefore focused on the exploitation of plant endophytes that produce manifold bioactive metabolites through cultivation-dependent methods, evaluating mainly endophytic fungi and Actinomycetes (Tan and Zou, 2001; Schulz et al., 2002; Strobel and Daisy, 2003; Gunatilaka, 2006) or Actinobacteria (rev. in Qin et al., 2010). To a lesser extent root-associated microorganisms have been prospected for secondary metabolites (Gunatilaka, 2006). Microbial production of manifold molecules like phytohormones, antibiotics and quorum-sensing molecules has been reported in plants. Cytokinins and auxins are plant growth regulators expressed by a vast amount of microbes, especially bacteria, allowing them to influence cell elongation and division in plants (Hayat et al., 2010). Particularly, the auxin indole-3-acetic acid, its biosynthesis and mode of action received much attention. Microbial indole3-acetic acid production can be of different consequence for plants, either detrimental as in crown gall formation induced by Agrobacterium tumefaciens or beneficial by promoting root development (rev in Duca et al., 2014), for instance.

Penicillin, the historical and classical example for microbial derived antibiotics is by far not the only microbial antibiotic produced and found. The production of such compounds is common among microorganisms. Examples of antimicrobial compounds synthesized by plant associated microbes include cyclosporine that is produced by the endophytic fungus Tolypocladium inflatum and shows antifungal activity (Borel et al., 1976). More recently discovered microbial antibiotics are antifungal ecomycins derived from the plant endophyte Pseudomonas viridiflava or turbomycin $A$ and $B$, which were identified from a soil derived metagenomic library (Miller et al., 1998; Gillespie et al., 2002). Bioactive compounds produced by plant associated microbes not only display antimicrobial but also antiviral activity. Xiamycin from Streptomyces sp. GT2002/1503, for instance, was reported to have anti-HIV properties (Ding et al., 2010).

Signaling compounds such as $\mathrm{N}$-acylhomoserine-lactones ( $\mathrm{AHL}$ ) and cyclic peptides play an important role in bacterial communication and bacterial-plant interactions, e.g. for regulation of bacterial swarming or biosynthesis of antibiotics and exopolysaccharides (Brelles-Mariño and Bedmar, 2001). Quorum sensing molecules have been well-characterized in plant-associated bacteria such as Rhizobium spp. (Downie, 2010) and Agrobacterium tumefaciens (Zhang et al., 2002). In addition to secondary metabolites, pathways or genes that confer resistance to heavy metals, salts and acids are of industrial interest. Using the rhizosphere metagenome of Erica andevalensis, a plant adapted to acid mine drainage at the banks of the Tinto River in Spain, 
Mirete et al. (2007) discovered novel nickel resistance genes and proposed mechanisms involved in metal resistance.

Another class of secondary metabolites are volatile organic compounds (VOCs) that are gaining more and more attention. In contrast to enzymes, VOCs and their possible biotechnological application have hardly been investigated, despite their beneficial effect on plant growth and health and their potential for biological control (Ryu et al., 2003; Müller et al., 2009). In fact, only little is known in regard to the enormous diversity of VOCs from microbial sources and their mode of action (Kanchiswamy et al., 2015). New volatiles were detected in plant-associated microorganisms (Strobel and Daisy, 2003; Kai et al., 2007; Bailly and Weisskopf, 2012). Bacterial volatiles can interact directly with plants, but they can also have a strong effect on fungal growth (Weisskopf, 2013). The observation that prokaryotes produce volatile compounds that are able to inhibit the growth of fungi is relatively new. In 2007, Kai and colleagues compared the volatilemediated inhibition of a range of phytopathogenic fungi by different bacterial strains. Since then, bacterial strains emitting antifungal volatiles, the chemical nature of those volatiles and their effect as pure compounds have been reported (recently reviewed by Effmert et al., 2012 and Weisskopf, 2013). However, despite of a long lists of VOCs produced by plant-associated bacteria, much less is known about the synthesis pathways. Widespread classes of volatiles emitted by bacteria are fatty acid derivatives (aliphatic volatiles e.g. butan-1-ol), terpenoids (e.g. geosmin, sesquiterpenes), and aromatic (e.g. 2-phenylethanol) or halogenated compounds (methyl iodine), as well as compounds containing nitrogen (e.g. ammonia, pyrazines) or sulfur (e.g. 3dimethylsulfoniopropionate) (Schulz and Dickschat, 2007; Kai et al., 2008). One of the most prominent anti-fungal volatiles is hydrogen cyanide, a respiratory poison, which is inappropriate for agricultural applications due to its high toxicity and lacking specificity (Blom et al., 2011). In the last years, the study of microbial volatile emissions has been confined to single cultivable bacterial species. Given the fact that more than $98 \%$ of the microbial diversity is not readily cultivable under current lab conditions (Handelsman, 2004), a search in metagenomes - bypassing the need of cultivation - is a promising approach.

Interesting industrial applications for microbial VOCs are bio-fumigation processes for developing crop welfare and sustainable agricultural practices (e.g. agricultural pre- and postharvest treatment) (Kanchiswamy et al., 2015) as well as for control of microbial hazards in human environments. The identification and analysis of novel secondary metabolites and their producers is yet another encouraging field, with an ever-growing demand for microbial and biochemical biopesticides. Moreover, VOCs can be applied as natural aroma chemicals, such as flavours and fragrances in the food and health care production industry (Krings and Berger, 1998). Some 
classes of VOCs produced by plant-associated bacteria are active against multi-resistant bacteria (Berg, pers. comm.), which can lead to the development of promising and novel concepts against the world-wide antimicrobial resistance challenge (Woolhouse and Farrar, 2014).

\section{Exploiting the first moss metagenome - a successful example for bioprospecting}

Our investigations on moss have revealed that the plant-associated microbiota represent a nearly untapped source for novel microbial functions, originating from species that are adapted to diverse biotic and abiotic conditions (Bragina et al., 2014). Mosses are considered model organisms for higher plants (Cove et al., 2009) and are therefore well suited for studying plant-microbiome interactions. Peat bogs are considered extreme habitat where mosses face extreme environmental conditions, such as high temperature fluctuations, repetitive desiccation, nutrient deficiency and high oxidative stress. The colonizing microorganisms are therefore highly specialized and display specific genetic features that distinguish them significantly from microbiomes of higher plants and peat soils, and support the symbiotic nature of the ecosystem. In silico analysis of the Sphagnum moss metagenome revealed increased abundance of functional groups that are responsible for stress tolerance and higher bacterial interaction through quorum sensing (e.g. autoinducer-2, AHL, and gamma-butyrolactones signaling pathways), biofilm formation, nutrient exchange (e.g. nitrogen cycling) and enhanced bacterial motility (Bragina et al., 2014). The occurrence of biosynthetic genes belonging to non-ribosomal peptide synthetases (NRPS) and polyketide synthases (PKS) was also investigated. Contigs containing NRPS and PKS sequences contributed $0.06 \%$ of the assembled metagenome, leading to detection of putative gene sequences coding for antibiotics, siderophores and phytotoxins (Müller et al., 2015). Bioprospecting for novel enzymes in the moss-associated microbiome has also been successful, yielding novel esterase, decarboxylase and phosphatase genes with potential application in biocatalytic processes (Müller, pers. comm.).

\section{Concluding remarks}

The phylogenetic and metabolic diversity hidden in plant-associated microorganisms is undeniable. This biosynthetic diversity can be regarded as highly diverse yet specialized and adapted to biotic and abiotic environmental conditions, making the discovery and exploitation of functional genes and secondary metabolites very promising. The full potential is hardly explored and should continue to be exploited. 


\section{Acknowledgement}

This manuscript was supported by different grants from the Austrian Science Foundation FWF (I183-B16; I 882-B16) to G.B. The cooperation of M.O. was funded by a project in the Austrian Centre of Industrial Biotechnology, supported by the Austrian BMWFW, BMVIT, SFG, Standortagentur Tirol, Government of Lower Austria and ZIT through the Austrian FFG-COMETFunding Program. We also gratefully acknowledge support from NAWI Graz.

\section{References}

Abbasian, F., Lockington, R., Megharaj, M., Naidu, R., 2015. The integration of sequencing and bioinformatics in metagenomics. Rev. Environmetal Sci. Biotechnol. 14, 357-383. doi:10.1007/s11157-015-9365-7

Atamna-Ismaeel, N., Finkel, O., Glaser, F., von Mering, C., Vorholt, J.A., Koblížek, M., Belkin, S., Béjà, O., 2012a. Bacterial anoxygenic photosynthesis on plant leaf surfaces. Environ. Microbiol. Rep. 4, 209216. doi:10.1111/j.1758-2229.2011.00323.x

Atamna-Ismaeel, N., Finkel, O.M., Glaser, F., Sharon, I., Schneider, R., Post, A.F., Spudich, J.L., von Mering, C., Vorholt, J.A., Iluz, D., Béjà, O., Belkin, S., 2012b. Microbial rhodopsins on leaf surfaces of terrestrial plants. Environ. Microbiol. 14, 140-146. doi:10.1111/j.1462-2920.2011.02554.x

Bailly, A., Weisskopf, L., 2012. The modulating effect of bacterial volatiles on plant growth. Plant Signal. Behav. 7, 79-85. doi:10.4161/psb.7.1.18418

Banerjee, J., Mishra, N., Dhas, Y., 2015. Metagenomics: A new horizon in cancer research. Meta Gene 5, 84-89. doi:10.1016/j.mgene.2015.05.005

Bérdy, J., 2012. Thoughts and facts about antibiotics: Where we are now and where we are heading. J. Antibiot. (Tokyo) 65, 385-395. doi:10.1038/ja.2012.27

Berg, G., 2009. Plant-microbe interactions promoting plant growth and health: perspectives for controlled use of microorganisms in agriculture. Appl. Microbiol. Biotechnol. 84, 11-18. doi:10.1007/s00253009-2092-7

Berg, G., Grube, M., Schloter, M., Smalla, K., 2014. Unraveling the plant microbiome: looking back and future perspectives. Plant-Microbe Interact. 5, 148. doi:10.3389/fmicb.2014.00148

Berg, G., Rybakova, D., Grube, M., Köberl, M., 2015. The plant microbiome explored: implications for experimental botany. J. Exp. Bot. erv466. doi:10.1093/jxb/erv466

Berg, G., Smalla, K., 2009. Plant species and soil type cooperatively shape the structure and function of microbial communities in the rhizosphere. FEMS Microbiol. Ecol. 68, 1-13. doi:10.1111/j.15746941.2009.00654.x

Berg, G., Zachow, C., Müller, H., Philipps, J., Tilcher, R., 2013. Next-generation bio-products sowing the seeds of success for sustainable agriculture. Agronomy 3, 648-656. doi:10.3390/agronomy3040648

Blaser, M.J., 2014. The microbiome revolution. J Clin Invest 124, 4162-5.

Blom, D., Fabbri, C., Eberl, L., Weisskopf, L., 2011. Volatile-Mediated Killing of Arabidopsis thaliana by Bacteria Is Mainly Due to Hydrogen Cyanide. Appl. Environ. Microbiol. 77, 1000-1008. doi:10.1128/AEM.01968-10

Borel, J.F., Feurer, C., Gubler, H.U., Stähelin, H., 1976. Biological effects of cyclosporin A: a new antilymphocytic agent. Agents Actions 6, 468-475. 
Bragina, A., Oberauner-Wappis, L., Zachow, C., Halwachs, B., Thallinger, G.G., Müller, H., Berg, G., 2014. The Sphagnum microbiome supports bog ecosystem functioning under extreme conditions. Mol. Ecol. 23, 4498-4510. doi:10.1111/mec.12885

Brelles-Mariño, G., Bedmar, E.J., 2001. Detection, purification and characterisation of quorum-sensing signal molecules in plant-associated bacteria. J. Biotechnol., Co-operation between Europe and Developing Countries on Research about Biological Nitrogen Fixation-Needa and Means 91, 197209. doi:10.1016/S0168-1656(01)00330-3

Bulgarelli, D., Garrido-Oter, R., Münch, P.C., Weiman, A., Dröge, J., Pan, Y., McHardy, A.C., Schulze-Lefert, P., 2015. Structure and function of the bacterial root microbiota in wild and domesticated barley. Cell Host Microbe 17, 392-403. doi:10.1016/j.chom.2015.01.011

Bulgarelli, D., Rott, M., Schlaeppi, K., Ver Loren van Themaat, E., Ahmadinejad, N., Assenza, F., Rauf, P., Huettel, B., Reinhardt, R., Schmelzer, E., Peplies, J., Gloeckner, F.O., Amann, R., Eickhorst, T., Schulze-Lefert, P., 2012. Revealing structure and assembly cues for Arabidopsis root-inhabiting bacterial microbiota. Nature 488, 91-95. doi:10.1038/nature11336

Cardinale, M., 2014. Scanning a microhabitat: plant-microbe interactions revealed by confocal laser microscopy. Front. Microbiol. 5. doi:10.3389/fmicb.2014.00094

Cardinale, M., Grube, M., Erlacher, A., Quehenberger, J., Berg, G., 2015. Bacterial networks and cooccurrence relationships in the lettuce root microbiota. Environ. Microbiol. 17, 239-252. doi:10.1111/1462-2920.12686

Castaneda-Alvarez, C., Prodan, S., Rosales, I.M., Aballay, E., 2015. Exoenzymes and metabolites related to the nematicidal effect of Rhizobacteria on Xiphinema index Thorne \& Allen. J. Appl. Microbiol. doi:10.1111/jam.12987

Coughlan, L.M., Cotter, P.D., Hill, C., Alvarez-Ordóñez, A., 2015. Biotechnological applications of functional metagenomics in the food and pharmaceutical industries. Front. Microbiol. 6. doi:10.3389/fmicb.2015.00672

Cove, D.J., Perroud, P.-F., Charron, A.J., McDaniel, S.F., Khandelwal, A., Quatrano, R.S., 2009. The moss Physcomitrella patens: a novel model system for plant development and genomic studies. Cold Spring Harb. Protoc. 2009, pdb.emo115. doi:10.1101/pdb.emo115

Cowan, D., Ramond, J.-B., Makhalanyane, T., De Maayer, P., 2015. Metagenomics of extreme environments. Curr. Opin. Microbiol., Environmental microbiology • Extremophiles 25, 97-102. doi:10.1016/j.mib.2015.05.005

Cretoiu, M.S., Berini, F., Kielak, A.M., Marinelli, F., van Elsas, J.D., 2015. A novel salt-tolerant chitobiosidase discovered by genetic screening of a metagenomic library derived from chitin-amended agricultural soil. Appl. Microbiol. Biotechnol. 99, 8199-8215. doi:10.1007/s00253-015-6639-5

Delmotte, N., Knief, C., Chaffron, S., Innerebner, G., Roschitzki, B., Schlapbach, R., Mering, C. von, Vorholt, J.A., 2009. Community proteogenomics reveals insights into the physiology of phyllosphere bacteria. Proc. Natl. Acad. Sci. 106, 16428-16433. doi:10.1073/pnas.0905240106

Ding, L., Münch, J., Goerls, H., Maier, A., Fiebig, H.-H., Lin, W.-H., Hertweck, C., 2010. Xiamycin, a pentacyclic indolosesquiterpene with selective anti-HIV activity from a bacterial mangrove endophyte. Bioorg. Med. Chem. Lett. 20, 6685-6687. doi:10.1016/j.bmcl.2010.09.010

Downie, J.A., 2010. The roles of extracellular proteins, polysaccharides and signals in the interactions of rhizobia with legume roots. FEMS Microbiol. Rev. 34, 150-170. doi:10.1111/j.15746976.2009.00205.x

Duca, D., Lorv, J., Patten, C.L., Rose, D., Glick, B.R., 2014. Indole-3-acetic acid in plant-microbe interactions. Antonie Van Leeuwenhoek 106, 85-125. doi:10.1007/s10482-013-0095-y

Duke, S.O., Cantrell, C.L., Meepagala, K.M., Wedge, D.E., Tabanca, N., Schrader, K.K., 2010. Natural toxins for use in pest management. Toxins 2, 1943-1962. doi:10.3390/toxins2081943

Effmert, U., Kalderás, J., Warnke, R., Piechulla, B., 2012. Volatile mediated interactions between bacteria and fungi in the soil. J. Chem. Ecol. 38, 665-703. doi:10.1007/s10886-012-0135-5 
Elleuche, S., Schäfers, C., Blank, S., Schröder, C., Antranikian, G., 2015. Exploration of extremophiles for high temperature biotechnological processes. Curr. Opin. Microbiol., Environmental microbiology • Extremophiles 25, 113-119. doi:10.1016/j.mib.2015.05.011

Faust, K., Lahti, L., Gonze, D., de Vos, W.M., Raes, J., 2015. Metagenomics meets time series analysis: unraveling microbial community dynamics. Curr. Opin. Microbiol., Environmental microbiology • Extremophiles 25, 56-66. doi:10.1016/j.mib.2015.04.004

Frankowski, J., Lorito, M., Scala, F., Schmid, R., Berg, G., Bahl, H., 2001. Purification and properties of two chitinolytic enzymes of Serratia plymuthica HRO-C48. Arch. Microbiol. 176, 421-426. doi:10.1007/s002030100347

Gabor, E., Liebeton, L., F, F., Eck, E., Lorenz, P., 2007. Updating the metagenomics toolbox. Biotechnol. J. 2, 201-206. doi:10.1002/biot.200600250

Garza, D.R., Dutilh, B.E., 2015. From cultured to uncultured genome sequences: metagenomics and modeling microbial ecosystems. Cell. Mol. Life Sci. 72, 4287-4308. doi:10.1007/s00018-015-20041

Gayathri, S., Saravanan, D., Radhakrishnan, M., Balagurunathan, R., Kathiresan, K., 2010. Bioprospecting potential of fast growing endophytic bacteria from leaves of mangrove and salt-marsh plant species. Indian J. Biotechnol. 9, 397-402.

Ghyselinck, J., Velivelli, S.L.S., Heylen, K., O’Herlihy, E., Franco, J., Rojas, M., De Vos, P., Prestwich, B.D., 2013. Bioprospecting in potato fields in the Central Andean Highlands: Screening of rhizobacteria for plant growth-promoting properties. Syst. Appl. Microbiol. 36, 116-127. doi:10.1016/j.syapm.2012.11.007

Gillespie, D.E., Brady, S.F., Bettermann, A.D., Cianciotto, N.P., Liles, M.R., Rondon, M.R., Clardy, J., Goodman, R.M., Handelsman, J., 2002. Isolation of antibiotics turbomycin A and B from a metagenomic library of soil microbial DNA. Appl. Environ. Microbiol. 68, 4301-4306.

Grube, M., Cernava, T., Soh, J., Fuchs, S., Aschenbrenner, I., Lassek, C., Wegner, U., Becher, D., Riedel, K., Sensen, C.W., Berg, G., 2015. Exploring functional contexts of symbiotic sustain within lichenassociated bacteria by comparative omics. ISME J. 9, 412-424. doi:10.1038/ismej.2014.138

Gunatilaka, A.A.L., 2006. Natural products from plant-associated microorganisms: Distribution, structural diversity, bioactivity, and implications of their occurrence. J. Nat. Prod. 69, 509-526. doi:10.1021/np058128n

Gu, X., Wang, S., Wang, S., Zhao, L.-X., Cao, M., Feng, Z., 2015. Identification and characterization of two novel esterases from a metagenomic library. Food Sci. Technol. Res. 21, 649-657. doi:10.3136/fstr.21.649

Handelsman, J., 2004. Metagenomics: Application of genomics to uncultured microorganisms. Microbiol. Mol. Biol. Rev. 68, 669-685. doi:10.1128/MMBR.68.4.669-685.2004

Hardoim, P.R., Overbeek, L.S. van, Berg, G., Pirttilä, A.M., Compant, S., Campisano, A., Döring, M., Sessitsch, A., 2015. The hidden world within plants: Ecological and evolutionary considerations for defining functioning of microbial endophytes. Microbiol. Mol. Biol. Rev. 79, 293-320. doi:10.1128/MMBR.00050-14

Harvey, A.L., 2008. Natural products in drug discovery. Drug Discov. Today 13, 894-901. doi:10.1016/j.drudis.2008.07.004

Hayat, R., Ali, S., Amara, U., Khalid, R., Ahmed, I., 2010. Soil beneficial bacteria and their role in plant growth promotion: a review. Ann. Microbiol. 60, 579-598. doi:10.1007/s13213-010-0117-1

Hirsch, P.R., Mauchline, T.H., 2012. Who's who in the plant root microbiome? Nat. Biotechnol. 30, 961962. doi:10.1038/nbt.2387

Inbar, J., Chet, I., 1991. Evidence that chitinase produced by Aeromonas caviae is involved in the biological control of soil-borne plant pathogens by this bacterium. Soil Biol. Biochem. 23, 973-978. doi:10.1016/0038-0717(91)90178-M 
Jansson, J.K., Neufeld, J.D., Moran, M.A., Gilbert, J.A., 2012. Omics for understanding microbial functional dynamics. Environ. Microbiol. 14, 1-3. doi:10.1111/j.1462-2920.2011.02518.x

Kai, M., Effmert, U., Berg, G., Piechulla, B., 2007. Volatiles of bacterial antagonists inhibit mycelial growth of the plant pathogen Rhizoctonia solani. Arch. Microbiol. 187, 351-360. doi:10.1007/s00203-0060199-0

Kai, M., Haustein, M., Molina, F., Petri, A., Scholz, B., Piechulla, B., 2008. Bacterial volatiles and their action potential. Appl. Microbiol. Biotechnol. 81, 1001-1012. doi:10.1007/s00253-008-1760-3

Kanchiswamy, C.N., Malnoy, M., Maffei, M.E., 2015. Chemical diversity of microbial volatiles and their potential for plant growth and productivity. Front. Plant Sci. 6. doi:10.3389/fpls.2015.00151

Kanokratana, P., Eurwilaichitr, L., Pootanakit, K., Champreda, V., 2015. Identification of glycosyl hydrolases from a metagenomic library of microflora in sugarcane bagasse collection site and their cooperative action on cellulose degradation. J. Biosci. Bioeng. 119, 384-391. doi:10.1016/j.jbiosc.2014.09.010

Kim, H.J., Jeong, Y.S., Jung, W.K., Kim, S.K., Lee, H.W., Kahng, H.-Y., Kim, J., Kim, H., 2015. Characterization of novel family IV esterase and family 1.3 lipase from an oil-polluted mud flat metagenome. Mol. Biotechnol. 57, 781-792. doi:10.1007/s12033-015-9871-4

Knief, C., 2014. Analysis of plant microbe interactions in the era of next generation sequencing technologies. Front. Plant Sci. 5. doi:10.3389/fpls.2014.00216

Knief, C., Delmotte, N., Chaffron, S., Stark, M., Innerebner, G., Wassmann, R., von Mering, C., Vorholt, J.A., 2012. Metaproteogenomic analysis of microbial communities in the phyllosphere and rhizosphere of rice. ISME J. 6, 1378-1390. doi:10.1038/ismej.2011.192

Krings, U., Berger, R.G., 1998. Biotechnological production of flavours and fragrances. Appl. Microbiol. Biotechnol. 49, 1-8. doi:10.1007/s002530051129

Kröber, M., Wibberg, D., Grosch, R., Eikmeyer, F., Verwaaijen, B., Chowdhury, S.P., Hartmann, A., Pühler, A., Schlüter, A., 2014. Effect of the strain Bacillus amyloliquefaciens FZB42 on the microbial community in the rhizosphere of lettuce under field conditions analyzed by whole metagenome sequencing. Front. Microbiol. 5. doi:10.3389/fmicb.2014.00252

Li, L.-L., Taghavi, S., McCorkle, S.M., Zhang, Y.-B., Blewitt, M.G., Brunecky, R., Adney, W.S., Himmel, M.E., Brumm, P., Drinkwater, C., Mead, D.A., Tringe, S.G., Lelie, D. van der, 2011. Bioprospecting metagenomics of decaying wood: mining for new glycoside hydrolases. Biotechnol. Biofuels 4, 113. doi:10.1186/1754-6834-4-23

Lumyong, S., Lumyong, P., McKenzie, E.H.., Hyde, K.D., 2002. Enzymatic activity of endophytic fungi of six native seedling species from Doi Suthep-Pui National Park, Thailand. Can. J. Microbiol. 48, 11091112. doi:10.1139/w02-112

Lundberg, D.S., Lebeis, S.L., Paredes, S.H., Yourstone, S., Gehring, J., Malfatti, S., Tremblay, J., Engelbrektson, A., Kunin, V., Rio, T.G. del, Edgar, R.C., Eickhorst, T., Ley, R.E., Hugenholtz, P., Tringe, S.G., Dangl, J.L., 2012. Defining the core Arabidopsis thaliana root microbiome. Nature 488, 86-90. doi:10.1038/nature11237

McChesney, J.D., Venkataraman, S.K., Henri, J.T., 2007. Plant natural products: Back to the future or into extinction? Phytochemistry, Phytochemical Society of North America 68, 2015-2022. doi:10.1016/j.phytochem.2007.04.032

Mendes, L.W., Kuramae, E.E., Navarrete, A.A., van Veen, J.A., Tsai, S.M., 2014. Taxonomical and functional microbial community selection in soybean rhizosphere. ISME J. 8, 1577-1587. doi:10.1038/ismej.2014.17

Mendes, R., Raaijmakers, J.M., 2015. Cross-kingdom similarities in microbiome functions. ISME J. doi:10.1038/ismej.2015.7

Miller, Miller, Garton-Kenny, Redgrave, Sears, Condron, Teplow, Strobel, 1998. Ecomycins, unique antimycotics from Pseudomonas viridiflava. J. Appl. Microbiol. 84, 937-944. doi:10.1046/j.13652672.1998.00415.x 
Mirete, S., Figueras, C.G. de, González-Pastor, J.E., 2007. Novel nickel resistance genes from the rhizosphere metagenome of plants adapted to acid mine drainage. Appl. Environ. Microbiol. 73, 6001-6011. doi:10.1128/AEM.00048-07

Müller, C.A., Oberauner-Wappis, L., Peyman, A., Amos, G.C.A., Wellington, E.M.H., Berg, G., 2015. Mining for NRPS and PKS genes revealed a high diversity in the Sphagnum bog metagenome. Appl. Environ. Microbiol. AEM.00631-15. doi:10.1128/AEM.00631-15

Müller, H., Westendorf, C., Leitner, E., Chernin, L., Riedel, K., Schmidt, S., Eberl, L., Berg, G., 2009. Quorum-sensing effects in the antagonistic rhizosphere bacterium Serratia plymuthica HRO-C48. FEMS Microbiol. Ecol. 67, 468-478. doi:10.1111/j.1574-6941.2008.00635.x

Nováková, J., Farkašovský, M., 2013. Bioprospecting microbial metagenome for natural products. Biologia (Bratisl.) 68, 1079-1086. doi:10.2478/s11756-013-0246-7

Nunes-Alves, C., 2014. Antimicrobials: Commensally sourced antibiotics. Nat. Rev. Drug Discov. 13, 812812. doi: $10.1038 / \mathrm{nrd} 4474$

Opelt, K., Berg, C., Berg, G., 2007. The bryophyte genus Sphagnum is a reservoir for powerful and extraordinary antagonists and potentially facultative human pathogens. FEMS Microbiol. Ecol. 61, 38-53. doi:10.1111/j.1574-6941.2007.00323.x

Ottesen, A.R., Gonzalez, A., Bell, R., Arce, C., Rideout, S., Allard, M., Evans, P., Strain, E., Musser, S., Knight, R., Brown, E., Pettengill, J.B., 2013. Co-enriching microflora associated with culture based methods to detect Salmonella from tomato phyllosphere. PLoS ONE 8, e73079. doi:10.1371/journal.pone.0073079

Pérez-Jaramillo, J.E., Mendes, R., Raaijmakers, J.M., 2015. Impact of plant domestication on rhizosphere microbiome assembly and functions. Plant Mol. Biol. 1-10. doi:10.1007/s11103-015-0337-7

Philippot, L., Raaijmakers, J.M., Lemanceau, P., van der Putten, W.H., 2013. Going back to the roots: the microbial ecology of the rhizosphere. Nat. Rev. Microbiol. 11, 789-799. doi:10.1038/nrmicro3109

Qin, S., Xing, K., Jiang, J.-H., Xu, L.-H., Li, W.-J., 2010. Biodiversity, bioactive natural products and biotechnological potential of plant-associated endophytic actinobacteria. Appl. Microbiol. Biotechnol. 89, 457-473. doi:10.1007/s00253-010-2923-6

Ramírez-Puebla, S.T., Servín-Garcidueñas, L.E., Jiménez-Marín, B., Bolaños, L.M., Rosenblueth, M., Martínez, J., Rogel, M.A., Ormeño-Orrillo, E., Martínez-Romero, E., 2013. Gut and root microbiota commonalities. Appl. Environ. Microbiol. 79, 2-9. doi:10.1128/AEM.02553-12

Ravin, N.V., Mardanov, A.V., Skryabin, K.G., 2015. Metagenomics as a tool for the investigation of uncultured microorganisms. Russ. J. Genet. 51, 431-439. doi:10.1134/S1022795415050063

Raymond, J.A., 2015. Dependence on epiphytic bacteria for freezing protection in an Antarctic moss, Bryum argenteum. Environ. Microbiol. Rep. n/a-n/a. doi:10.1111/1758-2229.12337

Robl, D., Delabona, P. da S., Mergel, C.M., Rojas, J.D., Costa, P. dos S., Pimentel, I.C., Vicente, V.A., da Cruz Pradella, J.G., Padilla, G., 2013. The capability of endophytic fungi for production of hemicellulases and related enzymes. BMC Biotechnol. 13, 94. doi:10.1186/1472-6750-13-94

Roossinck, M.J., Martin, D.P., Roumagnac, P., 2015. Plant Virus Metagenomics: Advances in virus discovery. Phytopathology. doi:10.1094/PHYTO-12-14-0356-RVW

Rudrappa, T., Czymmek, K.J., Paré, P.W., Bais, H.P., 2008. Root-secreted malic acid recruits beneficial soil bacteria. Plant Physiol. 148, 1547-1556. doi:10.1104/pp.108.127613

Ryu, C.-M., Farag, M.A., Hu, C.-H., Reddy, M.S., Wei, H.-X., Paré, P.W., Kloepper, J.W., 2003. Bacterial volatiles promote growth in Arabidopsis. Proc. Natl. Acad. Sci. 100, 4927-4932. doi:10.1073/pnas.0730845100

Schlaeppi, K., Dombrowski, N., Oter, R.G., Themaat, E.V.L. van, Schulze-Lefert, P., 2014. Quantitative divergence of the bacterial root microbiota in Arabidopsis thaliana relatives. Proc. Natl. Acad. Sci. 111, 585-592. doi:10.1073/pnas.1321597111 
Schmeisser, C., Steele, H., Streit, W.R., 2007. Metagenomics, biotechnology with non-culturable microbes. Appl. Microbiol. Biotechnol. 75, 955-962. doi:10.1007/s00253-007-0945-5

Schulz, B., Boyle, C., Draeger, S., Römmert, A.-K., Krohn, K., 2002. Endophytic fungi: a source of novel biologically active secondary metabolites. Mycol. Res. 106, 996-1004. doi:10.1017/S0953756202006342

Schulz, S., Dickschat, J.S., 2007. Bacterial volatiles: the smell of small organisms. Nat. Prod. Rep. 24, 814. doi:10.1039/b507392h

Sessitsch, A., Hardoim, P., Döring, J., Weilharter, A., Krause, A., Woyke, T., Mitter, B., Hauberg-Lotte, L., Friedrich, F., Rahalkar, M., Hurek, T., Sarkar, A., Bodrossy, L., van Overbeek, L., Brar, D., van Elsas, J.D., Reinhold-Hurek, B., 2011. Functional characteristics of an endophyte community colonizing rice roots as revealed by metagenomic analysis. Mol. Plant. Microbe Interact. 25, 28-36. doi:10.1094/MPMI-08-11-0204

Shcherbakov, A.V., Bragina, A.V., Kuzmina, E.Y., Berg, C., Muntyan, A.N., Makarova, N.M., Malfanova, N.V., Cardinale, M., Berg, G., Chebotar, V.K., Tikhonovich, I.A., 2013. Endophytic bacteria of Sphagnum mosses as promising objects of agricultural. Microbiology 82, 306-315. doi:10.1134/S0026261713030107

Simon, C., Daniel, R., 2011. Metagenomic analyses: past and future trends. Appl. Environ. Microbiol. 77, 1153-1161. doi:10.1128/AEM.02345-10

Stępniewska, Z., Kuźniar, A., 2013. Endophytic microorganisms-promising applications in bioremediation of greenhouse gases. Appl. Microbiol. Biotechnol. 97, 9589-9596. doi:10.1007/s00253-013-52359

Strobel, G., Daisy, B., 2003. Bioprospecting for microbial endophytes and their natural products. Microbiol. Mol. Biol. Rev. 67, 491-502. doi:10.1128/MMBR.67.4.491-502.2003

Suryanarayanan, T.S., Thirunavukkarasu, N., Govindarajulu, M.B., Gopalan, V., 2012. Fungal endophytes: an untapped source of biocatalysts. Fungal Divers. 54, 19-30. doi:10.1007/s13225-012-0168-7

Tan, R.X., Zou, W.X., 2001. Endophytes: a rich source of functional metabolites. Nat. Prod. Rep. 18, 448459. doi:10.1039/B1009180

Unno, Y., Shinano, T., 2013. Metagenomic analysis of the rhizosphere soil microbiome with respect to phytic acid utilization. Microbes Environ. 28, 120-127. doi:10.1264/jsme2.ME12181

van der Lelie, D., Taghavi, S., McCorkle, S.M., Li, L.-L., Malfatti, S.A., Monteleone, D., Donohoe, B.S., Ding, S.-Y., Adney, W.S., Himmel, M.E., Tringe, S.G., 2012. The metagenome of an anaerobic microbial community decomposing poplar wood chips. PLoS ONE 7, e36740. doi:10.1371/journal.pone.0036740

Vorholt, J.A., 2012. Microbial life in the phyllosphere. Nat. Rev. Microbiol. 10, 828-840. doi:10.1038/nrmicro2910

Wang, A., Xu, Y., Gao, Y., Huang, Q., Luo, X., An, H., Dong, J., 2014. Chemical and bioactive diversities of the genera Stachybotrys and Memnoniella secondary metabolites. Phytochem. Rev. 14, 623-655. doi:10.1007/s11101-014-9365-1

Weisskopf, L., 2013. The potential of bacterial volatiles for crop protection against phytophathogenic fungi, in: Méndez-Vilas, A. (Ed.), Microbial pathogens and strategies for combating them: Science, technology and education. Formatex Research Center.

Woolhouse, M., Farrar, J., 2014. Policy: An intergovernmental panel on antimicrobial resistance. Nat. News 509, 555. doi:10.1038/509555a

Zachow, C., Müller, H., Tilcher, R., Donat, C., Berg, G., 2013. Catch the Best: Novel screening strategy to select stress protecting agents for crop plants. Agronomy 3, 794-815. doi:10.3390/agronomy3040794 
Zachow, C., Tilcher, R., Berg, G., 2007. Sugar beet-associated bacterial and fungal communities show a high indigenous antagonistic potential against plant pathogens. Microb. Ecol. 55, 119-129. doi:10.1007/s00248-007-9257-7

Zhang, H.-B., Wang, L.-H., Zhang, L.-H., 2002. Genetic control of quorum-sensing signal turnover in Agrobacterium tumefaciens. Proc. Natl. Acad. Sci. 99, 4638-4643. doi:10.1073/pnas.022056699 
1 Table 1: Structural and functional diversity of plant-associated metagenomes.

\begin{tabular}{|c|c|c|c|c|c|}
\hline $\begin{array}{l}\text { Plant species } \\
\text { and habitat }\end{array}$ & $\begin{array}{l}\text { Taxonomic } \\
\text { structure: } \\
\text { Bacteria/ } \\
\text { Eukaryota/ } \\
\text { Archaea (\%) }\end{array}$ & $\begin{array}{l}\text { Dominant bacterial taxa } \\
(\%)\end{array}$ & $\begin{array}{l}\text { Characteristics } \\
\text { (location, habitat, } \\
\text { sampling, } \\
\text { treatments) }\end{array}$ & Functional diversity & Reference \\
\hline $\begin{array}{l}\text { Soybean } \\
\text { phyllosphere } \\
\text { (Glycine max } \\
\text { Gallec) }\end{array}$ & 99.07/ 0.58/ n.a. & $\begin{array}{l}\text { a-Proteobacteria }(42.8) \\
\text { Bacteroidetes }(12.1) \\
\text { B-Proteobacteria }(10.3) \\
\text { Actinobacteria }(9.8) \\
\text { ү-Proteobacteria }(5.3)\end{array}$ & $\begin{array}{l}\text { Effretikon } \\
\text { (Switzerland); } \\
\text { Agricultural practice: } \\
\text { field-grown plants, } \\
\text { sampling at beginning } \\
\text { of bean development. }\end{array}$ & $\begin{array}{l}\text { The analysed enzymatic functions focused on carbon and nitrogen cycling: } \\
\text { High abundance of outer membrane proteins (OprF), one-carbon compound } \\
\text { metabolism (methanol-DH), transport systems, carbon storage (phasin) and } \\
\text { stress-related proteins (chaperons GroEL) were detected. }\end{array}$ & $\begin{array}{l}\text { Delmotte et } \\
\text { al., } 2009\end{array}$ \\
\hline $\begin{array}{l}\text { Rice endosphere } \\
\text { (Oryza sativa } \\
\text { "APO') }\end{array}$ & n.a./n.a./ 0.4 & $\begin{array}{l}\text { B- \& } \mathrm{\gamma} \text {-Proteobacteria (61), } \\
\text { a-Proteobacteria (5.5), } \\
\text { Firmicutes (12), } \\
\text { Planctomycetes (1.3) }\end{array}$ & $\begin{array}{l}\text { Los Baños, } \\
\text { International Rice } \\
\text { Research Institute } \\
\text { (Philippines); Plants } \\
\text { grown on experimental } \\
\text { field, sampling at } \\
\text { flowering stage: } \\
\text { endophytes extracted } \\
\text { and enriched from } \\
\text { roots. }\end{array}$ & $\begin{array}{l}\text { Focus on metabolic systems for microbiome-host interactions: high } \\
\text { abundance of genes for protein secretion (cytoplasmic and outer membrane } \\
\text { proteins, type VI secretion system), plant-polymer-degrading enzymes } \\
\text { (cellulases, xylanases, cellobiohydrolases, pectinases, cellulose-binding } \\
\text { proteins), motility and adhesion (flagellins), detoxification of reactive oxygen } \\
\text { species (catalase, superoxide dismutase, glutathione peroxidase), } \\
\text { siderophores biosynthesis, quorum sensing systems (Al-2, homoserine } \\
\text { lactone), and nitrogen cycling; Availability of other enzymes involved in } \\
\text { butane-diol fermentation, aerobic degradation of aromatic, halogenated and } \\
\text { aliphatic compounds, and synthesis/degradation of polyhydroxyalkanoates } \\
\text { was detected. }\end{array}$ & $\begin{array}{l}\text { Sessitsch et } \\
\text { al., } 2011\end{array}$ \\
\hline $\begin{array}{l}\text { Rice } \\
\text { phyllosphere (P) } \\
\text { and rhizosphere } \\
(\mathbf{R})^{[\mathrm{b}]} \text { (Oryza sativa } \\
\text { subsp. indica cv. } \\
\text { IR-72) }\end{array}$ & $\begin{array}{l}\text { 99.5 P, 97.4 R/ } \\
\text { n.a./ 0.5 P, 2.6 R }\end{array}$ & 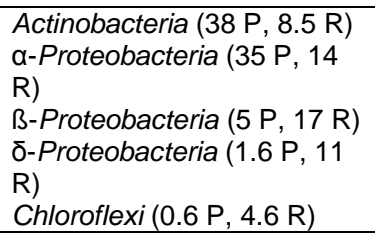 & $\begin{array}{l}\text { Los Baños } \\
\text { (Philippines); } \\
\text { Agricultural practice: } \\
\text { rice-field, sampling at } \\
59 \text { to } 76 \text { days after } \\
\text { seedling } \\
\text { transplantation. }\end{array}$ & $\begin{array}{l}\text { Abundant functions in the phyllosphere are: substrate uptake (porins, ABC } \\
\text { transport system), stress response, cell adhesion (fasciclin domain), one-- } \\
\text { carbon compound metabolism (methanol-DH), invasion-associated locus B- } \\
\text { family protein; in the rhizosphere: methanogenesis and methane oxidation, } \\
\text { dinitrogen fixation, chemotaxis and motility. }\end{array}$ & $\begin{array}{l}\text { Knief et al., } \\
2012\end{array}$ \\
\hline $\begin{array}{l}\text { Tamarisk } \\
\text { phyllosphere } \\
\text { (Tamarix nilotica) }\end{array}$ & n.a./n.a./n.a. & n.a. & $\begin{array}{l}\text { Oasis by the Dead } \\
\text { See (Israel); sampling } \\
\text { of leafs from T. nilotica } \\
\text { tree. }\end{array}$ & $\begin{array}{l}\text { Study focused on diversity of microbial rhodopsins: a higher abundance of } \\
\text { sensory rhodopsins over rhodopsin proton pumps was detected; mostly } \\
\text { novel rhodopsin sequences with uncertain phylogenetic affiliation were } \\
\text { detected. }\end{array}$ & $\begin{array}{l}\text { Atamna- } \\
\text { Ismaeel et } \\
\text { al., 2012b }\end{array}$ \\
\hline $\begin{array}{l}\text { Poplar wood } \\
\text { (Populus tremula) }\end{array}$ & $99.2 / 0.04 / 0.74$ & $\begin{array}{l}\text { Firmicutes (46), } \\
\text { Proteobacteria (32), } \\
\text { Bacteroidetes (10), } \\
\text { Cyanobacteria (4) }\end{array}$ & $\begin{array}{l}\text { USA; Non-sterile } \\
\text { yellow poplar saw dust } \\
\text { (indigenous } \\
\text { microbiota), } \\
\text { humidified; enrichment } \\
\text { of microbial } \\
\text { communities by } \\
\text { incubation at } 30^{\circ} \mathrm{C} \text { in } \\
\text { the dark for } 3 \text { and } 12 \\
\text { months. Sampling } \\
\text { from bottom fraction } \\
\text { (anaerobic zone). }\end{array}$ & $\begin{array}{l}\text { The study focused on detection of enzymatic functions for the anaerobic } \\
\text { degradation of recalcitrant plant biomass (lignin, cellulose, hemicellulose) } \\
\text { and carbohydrate active enzymes, using a BlastP homology search in CAZy } \\
\text { and FOLy databases: most abundant families are glycosyl transferases } \\
\text { (GT2, GT4) and glycoside hydrolases (GH13, GH3, GH2); present but less } \\
\text { abundant are bacterial genes with lower homology to fungal oxidase families } \\
\text { (cellobiose-DH, dihydrolipoamide-DH, peroxidases and multi-copper } \\
\text { oxidases). }\end{array}$ & $\begin{array}{l}\text { van der Lelie } \\
\text { et al., } 2012\end{array}$ \\
\hline
\end{tabular}




\begin{tabular}{|c|c|c|c|c|c|}
\hline $\begin{array}{l}\text { Tomato } \\
\text { phyllosphere } \\
\text { (Solanum } \\
\text { lycopersicum) }\end{array}$ & n.a. & $\begin{array}{l}\text { Proteobacteria (n.a.), } \\
\text { Firmicutes (n.a.), } \\
\text { Actinobacteria (n.a.), } \\
\text { Cyanobacteria (n.a.), } \\
\text { Chloroflexi (n.a.) }\end{array}$ & $\begin{array}{l}\text { Eastern Shore } \\
\text { Agricultural Research } \\
\text { and Extension Centre, } \\
\text { Virginia Tech (USA); } \\
\text { Leaves and fruits, } \\
\text { untreated control. }\end{array}$ & $\begin{array}{l}\text { Study focused on the effects of various culturing conditions (enrichment } \\
\text { treatments) rather than on functional characteristics of the tomato } \\
\text { phyllosphere. }\end{array}$ & $\begin{array}{l}\text { Ottesen et } \\
\text { al., } 2013\end{array}$ \\
\hline $\begin{array}{l}\text { Lotus japonicus } \\
\text { rhizosphere } \\
\text { (L. japonicus } \\
\text { MG20) }\end{array}$ & $\begin{array}{l}90.74 \mathrm{NT}, 87.23 \\
\mathrm{~F} / 5.45 \mathrm{NF}, 9.03 \\
\text { F/ } 3.03 \mathrm{NF}, 3.54 \\
\text { F }\end{array}$ & $\begin{array}{l}\text { Proteobacteria (43 NF; } 33 \mathrm{~F}) \\
\text { Acidobacterial Fibrobacteres } \\
\text { (13 NF; } 20 \mathrm{~F}) \\
\text { Actinobacteria (10 NF; } 13 \mathrm{~F}) \\
\text { Bacteroidetes/Chlorobi (10 } \\
\text { NF; } 6 \mathrm{~F}) \\
\text { Firmicutes (4.4 NF; } 5.8 \mathrm{~F}) \\
\text { Chloroflexi (3.4 NF; } 4.2 \mathrm{~F})\end{array}$ & $\begin{array}{l}\text { Hokkaido University } \\
\text { (Japan); Plant from } \\
\text { agricultural practice: } \\
\text { surface sterilized } \\
\text { seeds, plants grown in } \\
\text { green-house, analysis } \\
\text { of plants with addition } \\
\text { of phytic acid } \\
\text { (sampling at flowering } \\
\text { stage, F) or without } \\
\text { (not flowering, NF). }\end{array}$ & $\begin{array}{l}\text { Significantly increased abundance of functions for phosphorus-utilization in } \\
\text { plants supplemented with phytic acid (F) (alkaline phosphatase, myo-inositol } \\
\text { 1-monophosphatase, epi-inositol hydrolase; glutamine-, glutamate-, } \\
\text { aspartate- and asparagine-biosynthesis; glyoxylate synthesis), as well as } \\
\text { production of secondary metabolites (antibiotic compounds, phytohormones) } \\
\text { were observed; Other genes coding for outer membrane proteins, citrate } \\
\text { synthase, and glycosyl-transferase were detected. }\end{array}$ & $\begin{array}{l}\text { Unno and } \\
\text { Shinano, } \\
2013\end{array}$ \\
\hline $\begin{array}{l}\text { Soybean } \\
\text { rhizosphere } \\
\text { (Glycine max } \\
\text { Merril cv. M-SOY } \\
8866 \text { ) }\end{array}$ & $96 / 3 /<1$ & $\begin{array}{l}\text { Proteobacteria (47) } \\
\text { Actinobacteria (23) } \\
\text { Firmicutes (6) } \\
\text { Acidobacteria (5) }\end{array}$ & $\begin{array}{l}\text { University of Sao } \\
\text { Paulo (Brazil); } \\
\text { Soybean grown in } \\
\text { mesocosm (green- } \\
\text { house) using bulk soil } \\
\text { from Amazonian } \\
\text { agricultural fields, } \\
\text { sampling after } 80 \text { days } \\
\text { of growth, data for } 1 \\
\text { and } 5 \text { years of } \\
\text { soybean cultivation. }\end{array}$ & $\begin{array}{l}\text { Functional cores were analysed: the most representative metabolic systems } \\
\text { involve membrane transport (secretion system type IV), as well as } \\
\text { acquisition of nitrogen, phosphorus ( } P \text { uptake, alkylphosphonate utilization), } \\
\text { potassium and iron (heme, hemin uptake), which are overrepresented in the } \\
\text { rhizosphere as compared to bulk soil. Protein metabolism was most } \\
\text { abundant after } 1 \text { year, while regulation and cell signalling systems were more } \\
\text { abundant after } 5 \text { years of cultivation. }\end{array}$ & $\begin{array}{l}\text { Mendes et } \\
\text { al., } 2014\end{array}$ \\
\hline $\begin{array}{l}\text { Lettuce } \\
\text { rhizosphere }{ }^{[c]} \\
\text { (Lactuca sativa) }\end{array}$ & 98.2/ n.a./ n.a. & $\begin{array}{l}\text { Proteobacteria (64) } \\
\text { Actinobacteria (24) } \\
\text { Bacteroidetes (5) }\end{array}$ & $\begin{array}{l}\text { Golzow (Germany); } \\
\text { Agricultural practice: } \\
\text { field-grown plants } \\
\text { (untreated), } 0,2 \text { and } 5 \\
\text { weeks old plants after } \\
\text { planting from peat } \\
\text { blocks. }\end{array}$ & $\begin{array}{l}\text { Focus on functional subclasses of carbohydrate and nitrogen metabolism: } \\
\text { changes in saccharides, organic acids, amino acids and nitrogen metabolism } \\
\text { are dependent on growth state and substrate (peat or soil). }\end{array}$ & $\begin{array}{l}\text { Kröber et al., } \\
2014\end{array}$ \\
\hline $\begin{array}{l}\text { Moss } \\
\text { phyllosphere/ } \\
\text { endosphere } \\
\text { (Sphagnum } \\
\text { magellanicum) }\end{array}$ & 95.1/4.4/n.a. & $\begin{array}{l}\text { Proteobacteria (65.8), } \\
\text { Acidobacteria (11.4), } \\
\text { Actinobacteria (5.6), } \\
\text { Bacteroidetes (4.2) } \\
\text { Verrucomirobia (2.0) }\end{array}$ & $\begin{array}{l}\text { Pirker Waldhochmoor } \\
\text { (Austria); Extreme } \\
\text { abiotic conditions: } \\
\text { acidic pH, repetitive } \\
\text { desiccation, high } \\
\text { oxidative stress, high } \\
\text { temperature } \\
\text { fluctuations. }\end{array}$ & $\begin{array}{l}\text { Functions supporting genetic exchange (phages, type IV secretion), } \\
\text { resistance to oxidative stress (GSH/MSH/Rr reactions), and motility (flagella, } \\
\text { rhamnolipids) are highly abundant. High diversity of genes coding for quorum } \\
\text { sensing molecules (Al-2, homoserine lactones, } \mathrm{y} \text {-butyrolactones), biofilm } \\
\text { formation and adhesion (EPS, adhesins), toxin-antitoxin systems, antibiotics } \\
\text { and toxins (multidrug efflux pumps, Co-Zn-Cd resistance), DNA repair, NRPs } \\
\text { and PKs (toxins, siderophores, antibiotics) were also detected. }\end{array}$ & $\begin{array}{l}\text { Bragina et } \\
\text { al., } 2014 \text {; } \\
\text { Müller et al., } \\
2015\end{array}$ \\
\hline $\begin{array}{l}\text { Barley } \\
\text { rhizosphere } \\
\text { (Hordeum vulgare) }\end{array}$ & $\begin{array}{l}94.04 / 5.9 / \\
0.054\end{array}$ & $\begin{array}{l}\text { B-Proteobacteria (7.7) } \\
\text { Y-Proteobacteria (5.5), } \\
\text { Actinobacteria (n.a.), } \\
\text { Bacteroidetes (n.a.) }\end{array}$ & $\begin{array}{l}\text { Golm (Germany); } \\
\text { Agricultural practices: } \\
\text { green-house } \\
\text { cultivation of surface- } \\
\text { sterilized seeds, } \\
\text { sampling at early stem } \\
\text { elongation stage. }\end{array}$ & $\begin{array}{l}\text { Significant enrichment of protein coding sequences for adhesion, stress } \\
\text { response, and secretion systems was observed; Functions support host- } \\
\text { pathogen interactions (type III secretion system T3SS), microbe-microbe } \\
\text { interactions (type VI secretion system, T6SS), microbe-phage interactions } \\
\text { (transposable elements, bacteriophage integration), iron mobilization } \\
\text { (siderophores), and sugar transport; Plant effector proteins (T3SEs) and } \\
\text { phage protection systems (CRISPR-cas) were identified. }\end{array}$ & $\begin{array}{l}\text { Bulgarelli et } \\
\text { al., } 2015\end{array}$ \\
\hline
\end{tabular}


2 [a] Functional diversity analysed using metaproteome data; [b] Functional diversity analysed using a combination of metagenome and metaproteome data; [c] Data for alpha-diversity and taxonomic composition is given for 5 weeks old plants after planting; [d] Taxonomic composition was analysed by pyrotag sequencing, while functional diversity was analysed using the metagenomic dataset; Abbreviations: n.a.: not analysed; n.d.: not detected; GSH: glutathione; MSH: mycothiol; Rr: rubrerythrin; Al-2: autoinducer-2; EPS: extracellular polysaccharides; 5 NRPs: non-ribosomal peptides; PKs: polyketides; CRISPR: Clustered regularly interspaced short palindromic repeat system; cas: CRISPR-associated genes; R: rhizosphere; P: phyllosphere; 6 DH: dehydrogenase; F: flowering; NF: not flowering; CAZy: Carbohydrate-Active enZYmes database; FOLy: Fungal Oxidative Lignin enzYmes database. 